Egyptian Journal of Aquatic Biology \& Fisheries

Zoology Department, Faculty of Science,

Ain Shams University, Cairo, Egypt.

ISSN $1110-6131$

Vol. 25(2): 163 - 175 (2021)

www.ejabf.journals.ekb.eg

\title{
An Impact Assessment of Betani Irrigation Dam on Fish Diversity of Damak Municipality, Jhapa, Nepal
}

\author{
Jash Hang Limbu ${ }^{1, *}$, Jeevan Kumar Gurung ${ }^{2}$, Suren Subba ${ }^{3}$, Niraj Khadka ${ }^{4}$, \\ Ashim Adhikari ${ }^{4}$, Chitra Bahadur Baniya ${ }^{5}$ \\ 1.Nature Conservation and Health Care Council, Biratnagar, Nepal \\ 2. Damak Multiple Campus, Tribhuvan University, Damak, Jhapa, Nepal \\ 3. Dhankuta Multiple Campus, Tribhuvan University, Dhankuta, Nepal \\ 4. Central Department of Zoology, Tribhuvan University, Kirtipur, Kathmandu, Nepal \\ 5. Central Department of Botany, Tribhuvan University, Kirtipur, Kathmandu, Nepal \\ *Correspondence: limbujash@gmail.com
}

\section{ARTICLE INFO \\ Article History: \\ Received: Jan. 24, 2021 \\ Accepted: March 5, 2021 \\ Online: April 4, 2021}

Keywords:

Fish diversity,

Betani River,

fresh water,

hill stream,

conservation

\section{ABSTRACT}

The development of waterways or dam constructions without doing an environmental impact assessment (EIA) and fish ladder construction, alteration of aquatic environment, degradation of the quality of environmental variables, habitat modification and increasing fishing pressure have accelerated the vulnerability of fish in Nepal. To assess the impact of Betani River Dam on fish diversity and environmental parameters two major sampling stations were allocated along the sampling stretch with equal four sub-stations. Four substations at the upstream and four at the downstream. Sampling was conducted monthly from August 2020 to January 2021. A total of 6088 individuals, representing 29 species, were recorded in all catch samples. The species comprised 20 genera, 13 families and four orders. Of 29 fish species, the similarity percentage analysis (SIMPER) indicated that Puntius sophore (22.04\%), P. ticto (10.67\%), Lepidocephalus guntea (9.27\%), Danio devario (8.02\%), Puntius terio (7.52\%), Barilius barila (6.49\%) and Mystus tengera $(6.32 \%)$ were the major contributing fish species reported from Betani River. Analysis of similarity (ANOSIM) for space and time indicated that, there was a significant difference in spatial variation $(R=0.1946, P=0.0001)$, but none was recorded in time variation $(R=0.01703, P=0.3)$. One way analysis of similarity (ANOSIM) on the non-metric multidimensional scaling (NMDS) pointed a significant difference $(R=0.29, P=0.0001)$ between upstream and downstream of fish community structure in Betani River.

\section{INTRODUCTION}

Freshwater fishes are one of the most refuse to take notice fauna for conservation, as a result alarming reduction in fish diversity persevere (Shrestha et al., 2009), especially in urban south-east region of Nepal. The native fish reduction of Nepal is correlated with impoverished knowledge, expenditure, priority, water quantity and quality (Shrestha, 2001; Gurung and Baidya, 2012). Habitat destruction and fragmentation (For instance, transportation of boulders, cobbles, pebbles, sand mining, water diversion, hydro-power 
generation without fish ladder etc.), dynamiting, illegal electro-fishing, pollution, and use of poison herbs are responsible for declining native fish species of Nepal's rivers and rivulets (Gurung, 2012; Mishra \& Baniya, 2017; Limbu \& Prasad, 2020).The evolution of waterways, for hydropower generation and other groundwork development, has caused a substantial effect on aquatic biodiversity. Moreover, development of hydropower can limit or detain fish migration and also affect water quality and quantity and subject fish to direct harm and anxiety (Schilt, 2007 and Simonov et al., 2015). Regrettably some native fishes, such as Glyptothorax sps, Garra sps, Schizothorax sps, Tor sps and Neolissochilus hexagonolepis, that need high water current, cold, shallow, clean and oxygen rich gavel substrates, generally do not fare well in reservoirs and may be abolished (Bowen $\boldsymbol{e t}$ al., 2003). In Nepal, numerous dams have been established on the rivers and rivulets for redirecting the hydro-power generation and irrigation purposes. The Nepal's rivers and rivulets surging through the miscellaneous ecological kingdom hold diverse group of native, rare and endangered fish species that are short and long distance migratory in habitat. Short distance (for example; Schozothorax sps, Neolissochilus hexagonolepis, tor sps etc.) and long distance (for example; Anguilla bengalensis and Bagarius sps) migratory fish species have been found to be affected by dams (Asian Development Bank, 2018; Shrestha, 2019). Nevertheless, the feeding, reproduction, migratory routes, and behavior of the aquatic organisms are poorly understood. To this extent, it is difficult to detect locations for dams on the rivers and rivulets without noteworthy obstructing the migratory route of animals which have had consequential and irreparable influence on the rapid reduction in the inhabitants of numerous fish species (Asian Development Bank, 2018). Hence, this study was conducted to determine an impact assessment of Betani irrigation Dam on fish community structure, diversity, and inter-relation with habitat ecology and environmental variables of Damak Municiplaity, Jhapa, Nepal.

\section{MATERIALS AND METHODS}

\section{Study area}

The Betani River is situated at Damak Minicipality in Jhapa district (Fig. 1). It is a perennial river that originates from Beldangi two and three and flows through along the side of the Himalayan Tea Estate. The Damak Municipality to the east, Urlabari to the west, Baraghare to the South and Bhangbari to the north, are areas that surround the study area. The river bed mostly consists of sand, cobbles, pebbles and a few boulders. The upstream river bed consists of sand $(90 \%>)$, pebbles $(5 \%<)$ and cobbles $(5 \%<)$. On the other hand, downstream river bed consists of sand (70\%>), cobbles (10\%>), pebbles $(5 \%<)$ and boulders $(1 \%)$. The Betani River Dam is constructed near the Mahendra highway, and is mostly used for irrigation during the dry season. The vegetation of the river is mixed, mostly consisting of bamboo forest, Shorea robusta, Anthocephalus 
cadamba, Dalbergia sissoo, Ficura religiosa and bushes for upstream. On the contrary, the vegetation of the downstream mostly consisting of Shorea robusta, Anthocephalus cadamba, Dalbergia sissoo, bambusa spp and bushes.



Figure 1: Map of study area showing Betani River

\section{Data collection, preservation and identification}

To assess the impact of Betani River Dam on fish diversity and environmental parameters, two major sampling stations were allocated along the sampling stretch with equal four sub-stations. Four sub-stations at the upstream and four at the downstream. Sampling was conducted monthly from August 2020 to January 2021. In this study, each sampling site was $150-200 \mathrm{~m}$ long, and fish agglomeration was done for approximately 1:30 hour by cast net at each sampling site. The fishes were sampled using cast net of mesh size ranging from $6 \mathrm{~mm}$ to $10 \mathrm{~mm}$ mesh size, 25-33 feet length and 3.5-5 feet width, with the help of a local fisher man. Afterwards, the collected fishes were photographed with a Nikon digital camera (D5600, DX, 24.2 megapixels, Japan). After photography, about 5\% collected fish were preserved in $10 \%$ formaldehyde solution in plastic jar, keeping their head upside to protect their caudal fin. Whereas, the remaining samples were returned to their own natural habitat from where they were captured. The collected and preserved specimens were then, taken to the laboratory of the Department of Environment Science, Tribhuvan University, Damak, Jhapa, Nepal. The collected fish specimens were identified using standard taxonomic references (Talwar \& Jhingran, 1991; Jayaram, 2010) . The collected specimens at the field of survey were deposited in the laboratory of Damak Multiple Campus, Department of Environment Science, Tribhuvan University, Damak, Jhapa, Nepal.

The environmental variables measured during the field visit included: water temperature, dissolved oxygen $(\mathrm{DO}), \mathrm{pH}$ and water velocity. Water temperature $\left({ }^{\circ} \mathrm{C}\right)$ was measured using a digital thermometer (Hanna, HI98501, UK) by placing it in the water at a depth of 1 feet. The DO (mg/l) was measured by the Winkler titra-metric method, while 
pH was measured using a $\mathrm{pH}$ meter (HI98107, Hanna Instrument, UK). Water velocity was measured by the float method with the help of a stop watch, plastic ball and measuring tape. The proportion of substrates were categorized (substrate size $1=$ sand, silt $<2 \mathrm{~mm}, 2$ = gravel $<2-16 \mathrm{~mm}, 3=$ pebble $<17-64 \mathrm{~mm}, 4=$ cobble $<65-256 \mathrm{~mm}, 5=$ boulder $>256 \mathrm{~mm}$ ) and estimated visually, according to Bain $\boldsymbol{e t}$ al. (1985).

\section{Data analysis}

The Shannon-Weiner diversity index (Shannon and Weaver, 1963) was calculated using following formula:

$\mathrm{H}=\sum_{i=1}^{S} P i \leqslant \log P i$

Where $\mathrm{S}$ is the total number of species and $P i$ is the relative cover of $i_{\text {th }}$ of species.

To highlight the differences in environmental parameters (i.e, $\mathrm{pH}$, water temperature, dissolved oxygen and water velocity) and fish community attributes (i.e, Shannon index, Evenness index and Dominance index) between the different months and sites, the analysis of variance (ANOVA) was executed using the function aov in $\mathrm{R}$ software ( $\mathbf{R}$ core Team, Vienna, Austria). In the event of significance, a post hoc Tukey HSD test was used to determine which means were significantly different at a 0.05 level of probability (Spjotvoll \& Sttoline, 1973).

The correlation between fish community structure and environmental variables was first done by selection of appropriate tests a detrended correspondence analysis (DCA). The axis length and eigen value acquired from DCA suggested that the uni-model of canonical correspondence analaysis (CCA) was more applicable. Therefore, a direct multivariate ordination method (TerBraak, 1986), based on a linear response of species to environmental gradients, was applied by using vegan library in R (Oksanen, 2015). One-way analysis of similarity (ANOSIM) was used to conclude the significance of space and time variation of fish community structure (Clarke, 1993). Similarity percentages analysis (SIMPER) was executed to notice the percentage of similarity in temporal scale (Clarke, 1993).

\section{RESULTS}

Over the six months monitoring period, a total of 6088 individuals representing 29 species were recorded in all catch samples. The species comprised 20 genera, 13 families and four orders (Table 1). Among four orders, Cypriniformes was the most dominated order which comprised 55.17\%, followed by Siluriformes 24.13\%, Anabantiformes 13.79\%, and Synbranchiformes 6.89 of the total catch composition. Of 29 fish species, results from the similarity percentage analysis (SIMPER), $69.65 \%$ similarity was found among the months, while major contributing species were Puntius sophore $(22.04 \%), P$. 
ticto (10.67\%), Lepidocephalus guntea (9.27\%), Danio devario (8.02\%), Puntius terio (7.52\%), Barilius barila (6.49\%) and Mystus tengera (6.32\%). On the other hand, $70.77 \%$ similarity was found between the sites, and crucial contributing species were Puntius sophore (22.08\%), P. ticto (10.45\%), Lepidocephalus guntea (8.84\%), Danio devario (8.4\%), Puntius terio (7.12\%), Barilius barila (6.67\%) and Mystus tengera (6.34\%). Result of analysis of similarity (ANOSIM) for space and time indicated that, there was a significant difference in spatial variation $(R=0.1946, P=0.0001)$ but no significant difference was detected in time variation $(R=0.01703, P=0.3)$. The highest ShannonWeiner diversity index was recorded in December while the minimum was in November. On the other hand, maximum Shannon diversity value was recorded at station G, and the minimum was at station B (Fig. $2 \& 3$ ). The analysis of variance (ANOVA) suggested that there was no significant difference $(P>0.05)$ among the stations and months.

\section{Correlation between fish community structure and environmental parameters}

The canonical correspondence analysis (CCA) of first and second axis calculating for $13 \%$ and $10 \%$ respectively for the variation of data, was used for calculating the results (Fig. 4). Fish species of Danio devario, Pseudolaguvia kapuri, Mystus tengara, and Gogangra viridescens were highly associated with water temperature and water velocity, whereas species of Macrognathus pancalus, Heteropneustes fossilis, Clarius batrachus, Channa stewartii, Aspidoparia morar, Mystus cavasius, Acanthocobitis botia, Raiamas guttatus, Brachydanio rerio, and Esomus danrica were highly associated with dissolved oxygen and $\mathrm{pH}$. In contrast, the remaining fish species were not related to any variables. All the selected environmental variables were found to play an important role to determine the fish community structure of Betani River. One way analysis of similarity (ANOSIM) on the non-metric multidimensional scaling (NMDS) pointed a significant difference $(R=0.29, P=0.0001)$ between upstream and downstream of fish community structure in Betani River (Fig. 5). 
Table 1: Fish species collected from Betani River

\begin{tabular}{|c|c|c|}
\hline Order & Family & Species \\
\hline \multirow{16}{*}{ Cypriniformes } & \multirow{13}{*}{ Cyprinidae } & Labeo bata Hamilton-Buchanan, 1822 \\
\hline & & L. gonius Day, 1877 \\
\hline & & Puntius sophore Hamilton, 1822 \\
\hline & & P. ticto Hamilton, 1822 \\
\hline & & P. terio Hmailton, 1822 \\
\hline & & Barilius barila Day, 1878 \\
\hline & & Barilius bendilisis Hamilton, 1807 \\
\hline & & Barilius vagra Day, 1878 \\
\hline & & Aspidoparia morar Day, 1878 \\
\hline & & Raiamas guttatus Day, 1869 \\
\hline & & Brachydanio rerio Day, 1878 \\
\hline & & Danio devario Day, 1878 \\
\hline & & Esomus danrica Day, 1878 \\
\hline & Psilorhynchidae & Psilorhynchus balitora Day, 1877 \\
\hline & Nemacheilidae & Acanthocobitis botia Hamilton, 1822 \\
\hline & Cobitidae & Lepidocephalus guntea Rendahl, 1945 \\
\hline \multirow{7}{*}{ Siluriformes } & \multirow{3}{*}{ Bagridae } & Mystus cavasius Jayaram, 1977 \\
\hline & & Mystus vittatusBloch, 1797 \\
\hline & & Mystus tengara Misra, 1976 \\
\hline & \multirow[t]{2}{*}{ Sisoridae } & Gogangra viridescens Misra, 1976 \\
\hline & & Pseudolaguvia kapuri Tilak and Husain, 1974 \\
\hline & Claridae & Clarius batrachus Valencinnes, 1840 \\
\hline & Heteropneustidae & Heteropneustes fossilis Bloch, 1794 \\
\hline \multirow[b]{2}{*}{ Synbranchiformes } & Synbranchidae & Monopterus cuchia Rosem and Greenwood, 1976 \\
\hline & Mastacembelidae & Macrognathus pancalus Hamilton, 1822 \\
\hline \multirow[t]{4}{*}{ Anabantiformes } & Anabantoidae & Anabas testudineus Bloch, 1795 \\
\hline & Osphronemidae & Colisa faciatus Menon, 1974 \\
\hline & \multirow[t]{2}{*}{ Channidae } & Channa punctata Bloch, 1793 \\
\hline & & Channa stewartii Playfair, 1867 \\
\hline
\end{tabular}




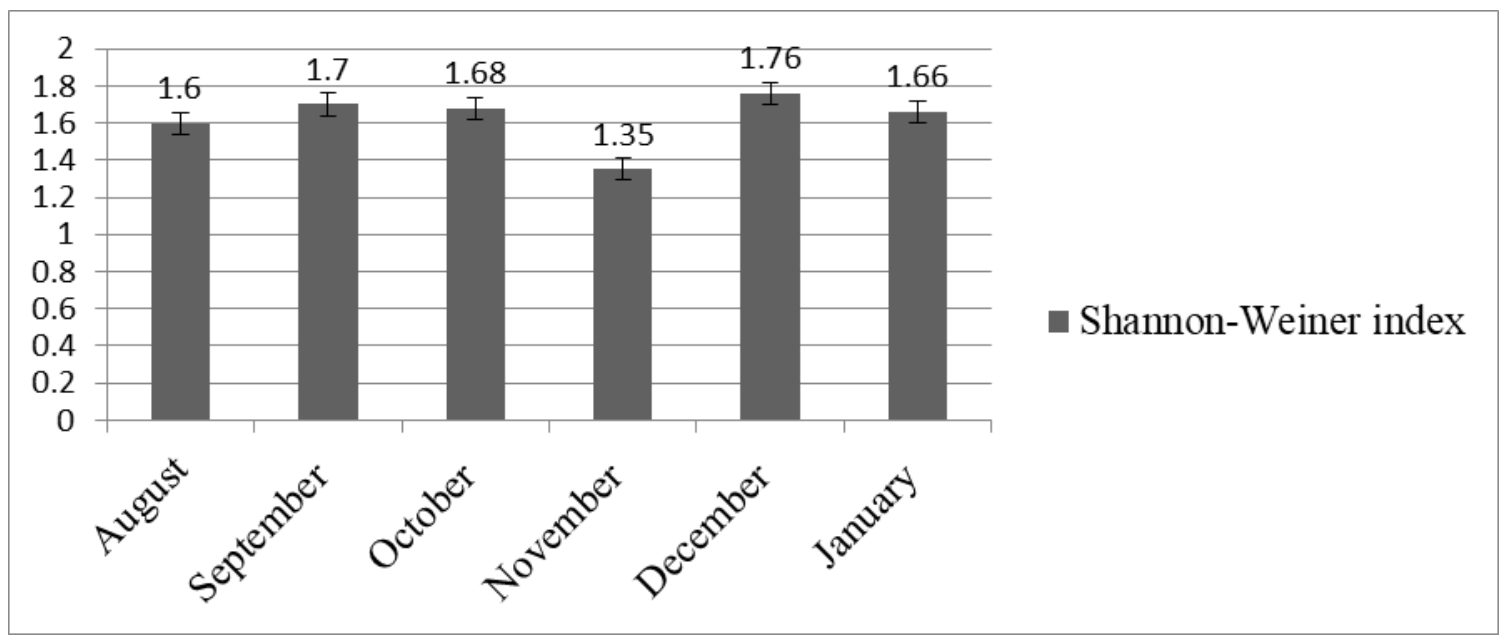

Figure 2: Month wise Shannon-Weiner diversity value

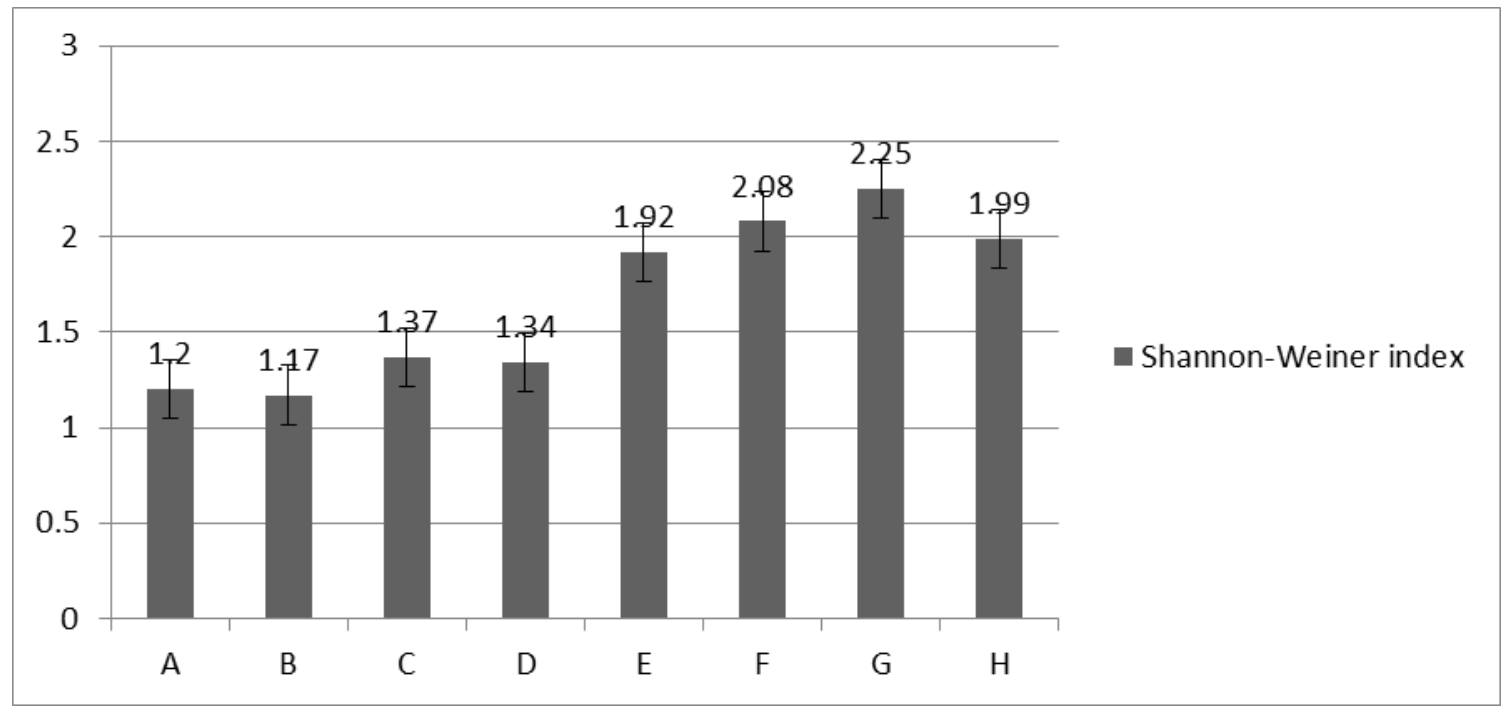

Figure 3: Station wise Shannon-Weiner diversity value 


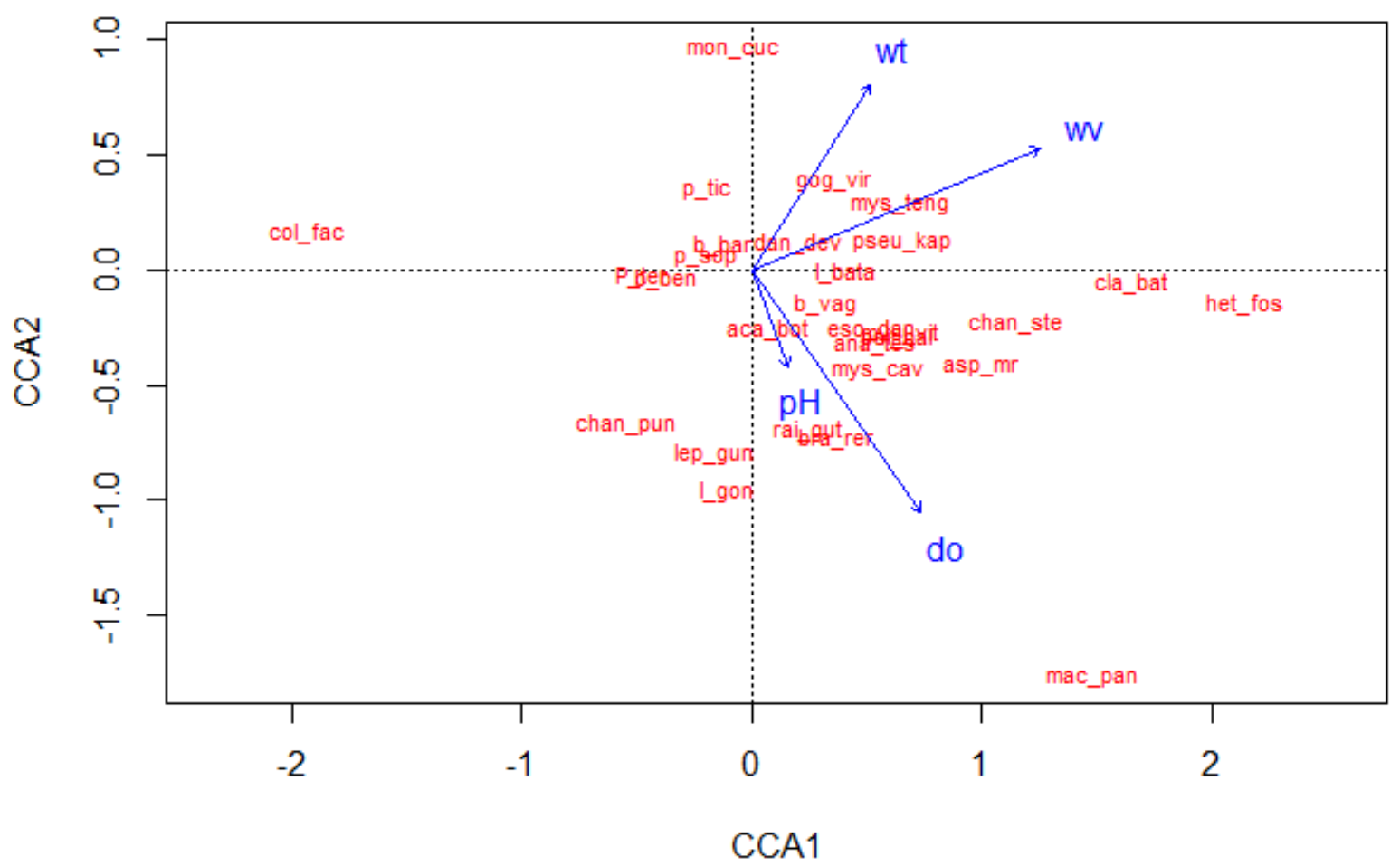

Figure 4: Biplot from canonical correspondence analysis (CCA) for the fish assemblages in the Betani River



Figure 5: NMDS biplot of the monthly fish abundance samples (with Bray-Curtis dissimilarity matrix), showing the Betani River fish community up-downstream variation 


\section{DISCUSSION}

A total of 29 fin fish were documented during the investigation period. Among them are Puntius sophore, P. ticto, P. terio, Lepidocephalus guntea, Danio devario, Barilius barila and Mystus tengera, each contributing more than $1 \%$ of the composition. The representation of Cypriniformes and Siluriformes orders found in this study is consistent with the information reported in the different rivers (Limbu et al., 2018; GC \& Limbu, 2019; Limbu et al. , 2019; Shrestha, 2019; Limbu \& Prasad, 2020; Limbu et al., 2020, Shrestha et al., 2020) of Bakraha, Ratuwa, Babai, Nuwa, Triyuga, Andhi, and Seti Gandaki. Nelson (2007) also indicated that the majority of freshwater fish falls under the order Cypriniformes. Based on the present analysis of similarity (ANOSIM) for space and time, there was a significant difference in spatial variation $(R=0.1946, P=0.0001)$, while no significant difference was shown in time variation $(R=0.01703, P=0.3)$. Fish community structure varies seasonally in response to internal and external factors (Belyea \& Lancaster, 1999; Yan, 2010; GC \& Limbu, 2019).

A biodiversity index seeks to characterize the diversity of samples by a single number (Magurran, 1988). The biodiversity index values, obtained from the present study, was neither so high according to Shannon-Weiner diversity index, nor showing any differences among the stations. The reason for showing lower species biodiversity is that fishing gears have high selectivity effect (Keskin \& Unsel, 1998). The highest Shannon-Weiner diversity index was recorded in December, while the minimum was in November. On the other hand, the maximum Shannon diversity value was recorded at station G, and the minimum was at station B. In each case, high Shannon-Weiner diversity index was involved with low individuals, and low diversity was involved with high number of individuals. The main causes of the differences occurring in the biodiversity indexes are the seasonal variations of nutrients at the sea grass beds affecting the coexistence of many fish species (Huh \& Kitting, 1985; Hossain et al., 2012), the seasonal fish migration (Ryer \& Orth, 1987), the atmospheric air currents and the environmental conditions (Keskin \& Unsel, 1998).

This study was the first to describe the impact assessment of space and time scale of fish community structure in the Betani River Dam of Damak municipality. Overall, it was found that the fish community structure of Betani River is highly affected by Betani irrigation dam, habitat modification and electro-fishing. The development of waterways, for hydropower and other industrial uses, has substantially altered many of the freshwater habitats of the planet and causing a considerable impact upon aquatic organisms. Industrial changes in aquatic ecosystems, including hydropower development, can restrict or delay fish migration, increase predation, affect water quantity and quality, and subject fish to direct damage and stress (Schilt, 2007). In the present study, river dam has found to be considerable impact on fish diversity. At upstream, only ten species viz; Channa punctatus, Lepidocephalus guntea, Acanthocobitis botia, Barilius bendelisis, B. barila, Puntius 
terio, P. sophore, P. ticto, Labeo gonius, and Colisa faciatus were reported, whereas at downstream, 20 fish species were documented. Dam construction can lower upstream fish richness by lowering fish movement (Holmquist et al., 1998; March et al., 2003). Dam construction may also modify the natural flow regime of species that complete their life cycles hinging on temporal flow, thus lowering their abundance (Bonner \& Wilde, 2000). One way analysis of similarity (ANOSIM) on the non-metric multidimensional scaling (NMDS) pointed a significant difference $(R=0.29, P=0.0001)$ between upstream and downstream of fish community structure in Betani River. Fish habitats can be damaged in obvious and subtle ways viewing big or small changes. For example, a fish habitat can be damaged by a large hydropower project or a poorly installed culvert that blocks the migratory route of endangered and vulnerable fish species. Among the most common threats to fish habitats are those associated with damming of rivers for water diversion, which usually produce dry river stretches downstream from the dam, destroying the riverine ecosystem (Asian Development Bank, 2018).

\section{CONCLUSION}

In this study, 29 fish species were subjected to examination, among which Puntius sophore, Puntius ticto, Puntius terio, Lepidocephalus guntea, Danio devario, Barilius barila and Mystus tengera were the contributory species, each contributing more than $1 \%$ of the total composition. Overall, it was found that the Betani irrigation Dam has substantially affected the fish community structure between up-downstream of Betani River. Therefore, an environment impact assessment (EIA) is recommended upon developing or constructing any river dam, whether small irrigation dams or hydro ones, in addition to the importance of constructing fish ladders.

\section{ACKNOWLEDGEMENT}

We would like to thank Mr. Aindra Kumar Limbu for the help of fish sampling and transportation. Our special thanks go to Damak Multiple Campus, Tribhuvan University, Department of Environment Science, Damak, Jhapa for providing us different water sampling kits.

\section{REFERENCES}

Asian Development Bank. (2018). Impact of Dams on fish in the Rivers of Nepal.

Belyea, L. R. and Lancaster, J. (1999). Assembly rules within a contingent ecology. Oikos 86: 402-441. 
Bonner, T. H. and Wilde G. R. (2000). Changes in the Canadian River fish assemblage associated with reservoir construction. Journal of Freshwater Ecology. 15: 189-198.

Bowen, Z. H.; Bovee, K. B. and Waddle, T. J. (2003). Effects of flow regulation on shallow-water habitat ASIAN dynamics and floodplain connectivity. Transactions of the American Fisheries Society. 132, 809-823.

Carl, R. S. (2007). Developing fish passage and protection at hydropower dams. Applied Animal Behaviour Science, 104: 295-325

Clarke, K. R. (1993). Non parametric multivariate analyses of changes in community structure. Australian Journal of Ecology 18, 11743

Gurung, T. B. and Baidya, A. P. (2012). Ex-situ breeding performance using pond reared broods of endangered Himalayan mahseer (Tor putitora) in Nepal, eds. Chettri, N; Sherchan, U; Chaudhary, S; Shakya, B (eds) Mountain biodiversity conservation and management: Selected examples of good practices and lessons learned from the Hindu Kush Himalayan region. ICIMOD Working Paper 2/2012. p 6-8.

Gurung, T. B. (2012). Native fish conservation in Nepal: Challenges and opportunities. Nepalese Journal of Biosciences 2: 71-79 (2012)

Holmquist, J. G,; Schmidt-Gengenbach, J. M. and Yoshioka, B. B. (1998). High dams and marine-freshwater linkages: Effects on native and introduced fauna in the Caribbean. Conservation Biology. 12: 621-630.

Hossain, M. S.; Das, N. G.; Sarker, S. and Rahaman, M. Z. (2012). Fish diversity and habitat relationship with Environmental vriables at Meghna river estuary, Bangladesh. Egyptian Journal of Aquatic Research. 38, 213-226.

Huh, S. H. and Kitting, C. L. (1985). Trophic relationships among concentrated populations of small fishes in seagrass meadows. Journal of Experimental Marine Biology and Ecology 92, 29-43.

Jayaram, K. C. (2010). The freshwater fishes of Indian region. Narendra Publishing House, Delhi, India, 614.

Keskin, C. and Unsal, N. (1998). The Fish Fauna of Gokceada Island, NE Aegean Sea. Turkey. Italian Journal of Zoology. 65:299-302.

Limbu, J. H and Gupta, S. (2019). Fish diversity of Damak and lower Terai region of Ratuwa River of Jhapa district, Nepal. International Journal of Fauna and Biological studies. 6(01-04) 
Limbu, J. H. Acharya, G. S. and Shrestha, O. M. (2018). A brief report on ichthyofaunal diversity of Dewmai Khola of Ilam district, Nepal. Journal of Natural History Museum Vol. 30. 312-317.

Limbu, J. H. and Prasad, A. (2020). Environmental variables and fisheries diversity of the Nuwa River, Panchthar, Nepal. Scientific World. Vol. 13, 69-74.

Limbu, J. H.; Baniya, C. B. and Prasad, A. (2019a). Spatio-Temporal Variation of Fish Assemblages in Ratuwa River, Ilam, Nepal. Journal of Ecology \& Natural Resources 3(3): 000168.

Limbu, J. H.; Prasad, A. and Shrestha, O. M. (2018). Ichthyofaunal diversity of Bakraha River of Morang district, Nepal. International Journal of Fisheries and Aquatic Studies. 6(5): 267- 271

Limbu, J. H.; Chapagain, N.; Gupta, S. and Sunuwar, S. (2019b). Review on fish diversity of eastern Nepal. International Journal of Fisheries and Aquatic Studies. 7(3): 177-181.

Limbu, J. H.; Bhurtel, B.; Adhikari, A.; Punam, G. C,; Maharjan, M. and Sunuwar, S. (2020). Fish community structure and environmental correlates in Nepal's Andhi Khola. Borneo Journal of Resources Science and Technology. Vol. 10(2): 85-92

Magurran, A. E. (1988). Ecological Diversity and its Measurement. Princeton University Press, Princeton

March, J. G.; Benstead, J. P.; Pringle, C. M. and Scatena, F. N. (2003). Damming tropical island streams: Problems, solutions, and alternatives. Bioscience. 53: 1069-1078.

Mishra, A. R, and Baniya, C. B. (2016). Ichthyofaunal Diversity and Physico-chemical Factors of MelamchiRiver,Sind-upalchok, Nepal. Journal of institute and science and technology. 21(1), 10-18.

Nelson, J. (2007). Fishes of the World. Fourth Edition. Hoboken, New Jersey, John Wiley and Sons.

Oksanen, J.; Blanchet, F. G.; Kindt, R.; Legendre „P.; Minchin, P. R.; Ohara, R. B.; Simpson, G. L.; Solymos, P.; Henry, M.; Stevens, H et al. (2015). Vegan: Community ecology package. $\mathrm{R}$ package version 2.3-1. Available from: http://CRAN.R-project. org/package=vegan

Prasad, A.; Shrestha, A.; Limbu, J.H. and Swar, D. (2020). Spatial and temporal variation of fish assemblage structure in Seti Gandaki River, Tanahu, Nepal. Borneo Journal of Resources Science and Technology. Vol. 10(2): 93-104 
Ryer, C. H. and Orth, R. J. (1987). Feeding ecology of the Northern pipefish, Syngnathus fuscus, in a Seagrass community of the lower chesapeake bay. Estuaries 10 (4), 330-336.

Shannon, C. E. and Wiener, W. (1949). The mathematical theory of communication. Urbana, Uiversity of Illinois Press, pp: 177.

Shrestha, J. (2001). Taxonomic revision of fishes of Nepal. In: Biodiversity, agriculture and pollution in South Asia. (Eds. P.K. Jha et.al.). ECOS, Kathmandu. pp. 171-180.

Shrestha, J.; Singh, D. M. and Saund, T. B. (2009). Fish diversity of Tamor River and its major tributaries of eastern Himalayan region of Nepal. Nepal Journal of Science and Technology. 219-223.

Shrestha, J. N. (2016). Fish diversity of Triyuga River, Udayapur District. Our Nature. 14(1):124-134.

Shrestha, T. K. (2019). Ichthyology of Nepal, A study of fishes of the Himalayan waters. Himalayan Ecosphere, Kathmandu, Nepal.

Simonov, E. A.; Nikitina, O. I. and Egidarev, E. G. (2015). River flood adaptation in the Amur Basin and nature conservation. Use Prot. Nat. Resour. Russ. Bull. 3, 1524.

Spjotvoll, E. and Stoline, M. R. (1973). An extension of the T-method of multiple comparisons to include the cases with unequal sample sizes. Journal of the American Statistical Association 68, 97678.

Talwar, P. K. and Jhingram, A. G. (1991). Inland Fisheries of India and Adjacent Countries. Volume I and II. Oxford and IBH Publishing Co. India, 1158.

terBraak, C. J. F. (1986). Canonical correspondence analysis-a new eigenvector technique for multivariate direct gradient analysis. Ecology 67(5): 1167-1179.

Yan, Y.; Shan, H. E.; Ling, C. H. U.; Xiuying, X.; Yanju, J. I. A.; Juan, T. A. O. and Yifeng, C. (2010). Spatial and temporal variation of fish assemblages in a subtropical small stream of the Huangshan Mountain. Current Zoology: 56(6): 670677. 